Abstracta Iranica Abstracta Iranica

Revue bibliographique pour le domaine irano-aryen

Volume 28 | 2007

Comptes rendus des publications de 2005

« Religious Disputations of Imāmī Shī'îs against Judaism in the late eighteenth and nineteenth centuries ». Studia Iranica, 34, 2005, pp. 95-134.

\title{
Denis Hermann
}

\section{(2) OpenEdition}

1 Journals

Édition électronique

URL : http://journals.openedition.org/abstractairanica/12702

DOI : 10.4000/abstractairanica.12702

ISSN : 1961-960X

Éditeur :

CNRS (UMR 7528 Mondes iraniens et indiens), Éditions de l'IFRI

\section{Édition imprimée}

Date de publication : 15 mai 2007

ISSN : 0240-8910

Référence électronique

Denis Hermann, « "Religious Disputations of Imāmī Shîis against Judaism in the late eighteenth and nineteenth centuries ». Studia Iranica, 34, 2005, pp. 95-134. », Abstracta Iranica [En ligne], Volume 28 | 2007, document 272, mis en ligne le 18 septembre 2007, consulté le 25 septembre 2020. URL : http:// journals.openedition.org/abstractairanica/12702 ; DOI : https://doi.org/10.4000/abstractairanica. 12702

Ce document a été généré automatiquement le 25 septembre 2020.

Tous droits réservés 


\section{« Religious Disputations of Imāmī Shī'ss against Judaism in the late eighteenth and nineteenth centuries ». Studia Iranica, 34, 2005, pp. 95-134.}

\section{Denis Hermann}

1 Cet article est une très intéressante analyse de l'argumentaire des religieux shi'ites d'époque qājār contre le judaïsme. Si les réfutations du judaïsme furent relativement peu nombreuses elles s'insérèrent dans un contexte favorable aux polémiques religieuses. L'arrivée régulière de missionnaires chrétiens en Iran à partir du règne de Fatḥ-'Alī Šāh (1211-1250/1797-1834), les revendications du Bāb et la naissance de la religion bahā'î, le regain de popularité du soufisme, le déclin considérable de l'akhbarisme et, parallèlement, la naissance de l'école théologico-mystique šeyHī encouragèrent ce type de littérature doctrinale. L'A. souligne que les ouvrages à l'encontre du judaïsme furent souvent à l'instigation de juifs récemment convertis à l'islam comme Qazvīnī Yazdī, Mohammad Redā Jadīd al-Islām ou Abābī. Ils s'adressaient avant tout aux communautés juives pour les convaincre de la validité de leur choix. Des débats publics furent également organisés par des religieux shi'ites dans lesquels les dirigeants des communautés juives étaient sommés de participer. La principale accusation à laquelle les juifs devaient répondre dans ces rencontres concerne les problèmes d'altérations de l'ancien testament (torah) ainsi que la lecture et l'interprétation de ce même texte par les savants juifs, notamment en matière de droit. Le principal objectif des 'olamā musulmans était de faire accepter aux représentants de la communauté juive le concept islamique d'abrogation (nasH) permettant de légitimer la prophétie de Moḥammad. 
INDEX

Thèmes : 7. Islam

\section{AUTEURS}

DENIS HERMANN

IFRI - Téhéran 